\title{
Hydrocarbons, Polyhalogenated
}

National Cancer Institute

\section{Source}

National Cancer Institute. Hydrocarbons, Polyhalogenated. NCI Thesaurus. Code C1895.

Hydrocarbons containing multiple halogen substituents $(\mathrm{Br}, \mathrm{Cl}, \mathrm{Fl}, \mathrm{I})$. 